\title{
Infantile hemangioma: timely diagnosis and treatment
}

Meerim Park, MD, PhD

Department of Pediatrics, Center for Pediatric Cancer, National Cancer Center, Goyang, Korea

\section{Key message}

While the majority of infantile hemangiomas (IHs) do not require therapy and regress spontaneously, about 10\%-15\% develop complications such as ulceration, obstruction, or disfigurement. Early intervention is recommended for infants with potentially problematic IHs. Oral propranolol $2-3 \mathrm{mg} / \mathrm{kg} /$ day is currently the treatment of choice.

Infantile hemangiomas (IHs) are the most common benign tumors of infancy. IHs have a distinct natural history involving early proliferative, quiescent plateau, and involution phases. Eighty percent of all IHs peak in size by 3 months' patient age, followed by spontaneous regression. ${ }^{1)}$ Their clinical course during any phase, particularly the proliferative phase, can cause significant morbidity and mortality.

IHs are usually diagnosed clinically. Biopsy and pathological diagnosis are required only when the IH lesion must be differentiated from borderline or malignant vascular tumors. Imaging studies and other investigations are required in special situations
(Table 1).

Most cutaneous IHs are uncomplicated; however, approximately 10\%-15\% require treatment. ${ }^{2}{ }^{2}$ Indications for treatment include life-threatening nature (causing heart failure or respiratory distress), risk of functional impairment such as visual obstruction or feeding difficulties, ulceration, and severe anatomic distortion, especially on the face. ${ }^{3)} \mathrm{A}$ patient with $\mathrm{IH}$ who is at risk of complications should be referred to a multidisciplinary team for evaluation, specific diagnostic measures (e.g., magnetic resonance imaging, screening for hypothyroidism, or coagulation abnormalities), and specific treatment.

The most common treatment modality during the proliferative phase is medical, which aims to minimize or prevent the development of morbidity. Effective medical treatment during proliferation can minimize or prevent the future need for surgical debulking and recontouring. IHs manifesting as obstructions or ulcerations require immediate therapy.

Propranolol can be the first-line treatment. Hemangiol ${ }^{\circledR}$, a liquid formulation of propranolol, was approved by the U.S. Food

Table 1. Imaging studies and other investigations in patients with infantile hemangioma

\begin{tabular}{|c|c|c|}
\hline Investigations & Indication & Purpose \\
\hline Ultrasound with doppler & $\begin{array}{l}\text { Deep or multifocal IH } \\
\text { Screening for hepatic IH } \\
\text { Segmental IH } \\
\text { PHACE syndrome } \\
\text { Midline IH of the lumbosacral area } \\
\text { Differential diagnosis of other vascular anomalies }\end{array}$ & $\begin{array}{l}\text { Initial imaging study when the diagnosis of } \mathrm{IH} \text { is uncertain } \\
\text { Evaluate death and size of } \mathrm{IH} \\
\text { Evaluate number and size of intrahepatic tumor } \\
\text { Rule out occult spinal dysraphism } \\
\text { Rule out renal and urogenital anomalies }\end{array}$ \\
\hline Echocardiography & $\begin{array}{l}\text { Large or multifocal IH } \\
\text { PHACE syndrome } \\
\text { Lumbosacral IH }\end{array}$ & $\begin{array}{l}\text { Rule out cardiac insufficiency } \\
\text { Rule out cardiac or aortic anomaly }\end{array}$ \\
\hline MRI/MRA & $\begin{array}{l}\text { Segmental IH } \\
\text { Lumbosacral IH } \\
\text { PHACE syndrome }\end{array}$ & $\begin{array}{l}\text { MRI/MRA of the head and neck for large segmental facial or scalp IH } \\
\text { Spine MRI for lumbosacral IH, especially when there is sacral dimple, } \\
\text { skin appendage, hair tuft, or lipoma }\end{array}$ \\
\hline Ophthalmological exam & $\begin{array}{l}\text { Periorbital IH } \\
\text { PHACE syndrome }\end{array}$ & Rule out eye anomalies and ophthalmologic problem \\
\hline Coagulation screening & Multifocal intrahepatic IH & Rule out disseminated intravascular coagulopathy \\
\hline $\begin{array}{l}\text { Thyroid-stimulating } \\
\text { hormone screening }\end{array}$ & Large or multifocal IH & $\begin{array}{l}\text { Rule of secondary hypothyroidism } \\
\text { IH can produce an excess of thyroid hormone inactivating enzyme } \\
\text { type-3 iodothyronine deiodinase (D3), leading to rapid degradation } \\
\text { of thyroid hormone and consumptive hypothyroidism }\end{array}$ \\
\hline
\end{tabular}

IH, infantile hemangioma; PHACE, posterior fossa anomalies, hemangioma, arterial anomalies, cardiac anomalies, and eye anomalies; MRI, magnetic resonance imaging; MRA, magnetic resonance angiography.

Corresponding author: Meerim Park, MD, PhD, Department of Pediatrics, Center for Pediatric Cancer, National Cancer Center, 323 Ilsan-ro, Ilsandong-gu, Goyang 10408, Korea 
and Drug Administration for the treatment of IHs in 2014. ${ }^{4)}$ The efficacy of propranolol was first discovered when two infants with large IHs showed signs of cardiac failure.5) Propranolol was initiated for their cardiac indications, but the IHs regressed rapidly. A randomized controlled trial of propranolol demonstrated its efficacy at discoloring and reducing tumor volume without causing significant adverse events (AEs). ${ }^{6}$ Guidelines on the initiation and management of infants taking propranolol have been established.7) The goal dose is usually $2-3 \mathrm{mg} / \mathrm{kg} / \mathrm{day}$ in divided doses. Although the IH shrinks rapidly with oral propranolol, a minimum of 6 months of therapy is recommended. Recurrence after the discontinuation of propranolol occurs in $10 \%-15 \%$ of cases. $\left.{ }^{8}\right)$ IHs with structural anomalies, including PHACE syndrome (posterior fossa malformations, hemangioma, arterial anomalies, cardiac anomalies, and eye anomalies) are not contraindicated for propranolol treatment, but extreme caution is needed. Topical timolol has gained popularity as a low-risk alternative for treating smaller superficial IHs. For patients with contraindications to propranolol, such as bronchial asthma, atrioventricular block II-III, proneness to hypoglycemia, hypersensitivity to propranolol, pheochromocytoma, and corticosteroids, should be considered. A recent randomized clinical trial directly comparing corticosteroids to propranolol demonstrated similar efficacy with comparable AEs, although the corticosteroid group had more severe AEs. ${ }^{9}$ Surgery is rarely indicated during the proliferative phase except for diagnostic confirmation or in cases of rapidly proliferating $\mathrm{IH}$ s causing arterial bleeding.

After incomplete regression, excessive fibrofatty tissue and scars can raise cosmetic concerns. There are limited indications for medical therapy to treat IHs beyond the proliferative phase. Laser therapy may be indicated to correct persistent coarse telangiectasia after IH involution. In cases of contour deformities, the only treatment option is surgical debulking and recontouring of the affected areas.

The treatment of IHs incorporates a wide range of modalities. It is imperative to understand the different growth phases of IHs and the morbidities that can occur at each phase. The early detection of at-risk $\mathrm{IH}$ is a major point requiring increased awareness by pediatricians, general practitioners, and health specialists to identify potentially problematic IHs within the first $2-3$ weeks of life so that they can be treated during the early stage of proliferation.
See the article "Update on infantile hemangioma" via https:// doi.org/10.3345/cep.2020.02061.

\section{Footnotes}

Conflicts of interest : No potential conflict of interest relevant to this article was reported.

ORCID

Meerim Park @ https://orcid.org/0000-0002-6847-9447

\section{References}

1. Chang LC, Haggstrom AN, Drolet BA, Baselga E, Chamlin SL, Garzon $\mathrm{MC}$, et al. Growth characteristics of infantile hemangiomas: implications for management. Pediatrics 2008;122:360-7.

2. Leaute-Labreze C, Harper JI, Hoeger PH. Infantile haemangioma. Lancet 2017;390:85-94.

3. Garzon MC, Frieden IJ. Hemangiomas: when to worry. Pediatr Ann 2000; 29:58-67.

4. Jung HL. Update on infantile hemangioma. Clin Exp Pediatrics 2021;64: 559-72.

5. Leaute-Labreze C, Dumas de la Roque E, Hubiche T, Boralevi F, Thambo JB, Taieb A. Propranolol for severe hemangiomas of infancy. NEngl J Med 2008;358:2649-51.

6. Leaute-Labreze C, Hoeger P, Mazereeuw-Hautier J, Guibaud L, Baselga E, Posiunas G, et al. A randomized, controlled trial of oral propranolol in infantile hemangioma. NEngl J Med 2015;372:735-46.

7. Drolet BA, Frommelt PC, Chamlin SL, Haggstrom A, Bauman NM, Chiu YE, et al. Initiation and use of propranolol for infantile hemangioma: report of a consensus conference. Pediatrics 2013;131:128-40.

8. Bagazgoitia L, Hernandez-Martin A, Torrelo A. Recurrence of infantile hemangiomas treated with propranolol. Pediatr Dermatol 2011;28:65862.

9. Bauman NM, McCarter RJ, Guzzetta PC, Shin JJ, Oh AK, Preciado DA, et al. Propranolol vs prednisolone for symptomatic proliferating infantile hemangiomas: a randomized clinical trial. JAMA Otolaryngol Head Neck Surg 2014;140:323-30.

How to cite this article: Park M. Infantile hemangioma: timely diagnosis and treatment. Clin Exp Pediatr 2021;64:5734. https://doi.org/10.3345/cep.2021.00752 